\title{
THE INFLUENCE OF CUSTOMER RELATIONSHIP MANAGEMENT (CRM) ON CUSTOMER LOYALTY IN JW MARRIOTT HOTEL SURABAYA
}

\author{
Fransisca Andreani, Yesslyn Sumargo, dan Chen Lie \\ Faculty of Economics, Petra Christian University, Surabaya, Indonesia \\ Email: andrea@peter.petra.ac.id
}

\begin{abstract}
Customer Relationship Management (CRM) is one of strategies to retain customers. By maintaining the relationship with customers, hopefully they will be loyal to companies. The objective of this study is to determine the influence of CRM on customer loyalty in JW Marriott Hotel, Surabaya using multiple linear regression analysis. The results of this study show that CRM, including financial benefits, social benefits and structural ties have positive effects significantly on customer loyalty in JW Marriott Hotel Surabaya. The most dominant factor influencing customer loyalty in JW Marriott Hotel, Surabaya is the structural ties.
\end{abstract}

Keywords: Customer Relationship Management (CRM), Customer Loyalty JW Marriott Hotel

\begin{abstract}
Abstrak
Customer Relationship Management (CRM) merupakan salah satu strategi untuk mempertahankan pelanggan. Dengan terjalinnya hubungan yang erat diharapkan pelanggan menjadi loyal pada perusahaan. Penelitian ini bertujuan untuk mengetahui pengaruh CRM terhadap loyalitas pelanggan di Hotel JW Marriott Surabaya dengan teknik analisis regresi linier berganda. Hasil penelitian menunjukkan bahwa CRM yang meliputi financial benefits, social benefits dan structural ties berpengaruh positif dan signifikan terhadap loyalitas pelanggan Hotel JW Marriott Surabaya. Faktor yang berpengaruh dominan terhadap loyalitas pelanggan Hotel JW Marriott Surabaya adalah structural ties.
\end{abstract}

Kata Kunci: Customer Relationship Management (CRM), Loyalitas Pelanggan, JW Marriott Hotel.

\section{INTRODUCTION}

Due to rapid hotel development, the rivalry in hotel industries is getting tighter. One of the five-star hotels in Surabaya, JW Marriott Hotel, a rebranding of the Marriott International also tries to compete with other hotels by focusing on retaining its customers. This is appropriate as loyal customers may provide consistent revenue by making repurchases and can reduce costs. The hotel can save its marketing cost. By doing so, the hotel can increase its profitability. Shoemaker and Lewis (1999) stated that marketing has shifted from customer acquisition to customer retention or loyalty. In addition, Mcllroy and Barnett (2000) state that the cost to get new customers is five times more expensive than the cost to maintain existing customers. Loyal customers will always give positive comments and recommendation about the company to others.

Customer Relationship Management (CRM) is one of marketing strategies popularly applied to retain customers. According to Kotler and Armstrong (2004), Customer Relationship Management (CRM) is a process of building and maintaining long range relationship which is beneficial for both customers and companies. Hotel and airline industries as well as retail companies have also implemented CRM by providing financial, social benefits and structural ties to their customers.

JW Marriott Hotel in Surabaya has also implemented CRM by having Marriott Rewards Program. It is a program done for all hotel brands under Marriott International, including JW Marriott, Edition, Autograph Collection, Renaissance Hotels, AC Hotels Marriott, Marriott Hotels \& Resorts, Marriott Vacation Club, Courtyard Marriott, Fairfield Inn \& Suites Marriott, Springhill Suites Marriott, Residence Inn Marriott, TownePlace Suites Marriott, and The Ritz Carlton ${ }^{\circledR}$.

Based on personal interview with Ms. Zoraya on $24^{\text {th }}$ February 2012, the objectives of Marriott Rewards Program are to maintain positive words of 
mouth (WOM) from those who stay in the hotels, to make customers come back to the hotels and to increase hotel performance and facilities. It can be said that the main objective is to get qualified and loyal customers. Furthermore, she stated that Marriott Rewards Program uses earning points method for its customers. For every single US\$ spent for normal room rate charge in JW Marriott Hotel Surabaya, members of Marriott Rewards Program will get additional 10 points and will be multiplied accordingly. These points can be redeemed with rewards provided by the hotels under Marriott International.

JW Marriott Hotel Surabaya has provided Marriott Rewards for almost 10 years and this program has already been implemented by Marriott International hotels around the world for about 50 years. But so far there is no research done to find out the influence of Marriott Rewards Program as part of CRM towards customer loyalty in JW Marriott Hotel Surabaya. That is why the writers are interested to explore the influence of CRM, especially Marriott Rewards Program, on customer loyalty in JW Marriott Hotel Surabaya. This research is limited to the financial, social benefits and structural ties offered by Marriott Rewards Program. Research problem in this study: do financial, social benefits and structural ties influence customer loyalty in JW Marriott Hotel Surabaya?

\section{LITERATURE REVIEW AND HYPOTHESIS}

Customer Relationship Management (CRM) is a strategy to maintain relationship with customers in order to get profitable long term relationship between companies and their customers. Each customer wants to be treated differently according to his/ her needs. That is why a lot of companies start to use CRM as a way to maintain their relationship with the customers (Persson, 2004).

In addition, Persson (2004) mentions the objecttives of CRM are as follows:

1. Cost savings to get customers

Cost allocation to get customers can be decreased as marketing costs also decrease, including the expenses to get new customers and to serve customers.

2. No need to get new customers in order to stabilize business operation

The number of loyal customers will grow more and automatically the need to get new customers can be less.

3. Reduce promotion costs

Promotion costs can be reduced as existing customers become responsive. Besides that, the growing number of new distributors will make the relationship between the company and its customers become more effective.

4. More profits from customers

As customers buy more, the company will get more profits. The increasing profits can be from up-selling, cross-selling, follow-up sales, and others as a result of the existing satisfied customers.

5. Increase customer satisfaction

Customer satisfaction increases when costumers become loyal to the company, buy more than they use to be and repeatedly. Customers have more initiatives to maintain their relationships with the company so that it increases customer loyalty.

6. Evaluate profits from customers

The company will be able to know which customers are profitable or not profitable as well as which ones are more profitable in the future. It is very important as the key success in every business is to focus on retaining customers who are profitable and maintaining the relationship with them well.

Kotler and Armstrong (2004) also state that Customer Relationship Management (CRM) is a process of building and maintaining long term relationship which is beneficial for customers. There are three approaches to maintain and develop the company's relationship with its customers:

1. Financial benefits

Customers will get financial benefits when the price of the product is lower than other competitors so they can save some money. The implementation of these benefits can be in the form of special discounts as a reward, especially when customers buy in a big volume or when they buy products on a regular basis.

2. Social Benefits

Companies need to provide social benefits to their customers. Social benefits help to improve relations by studying customers' needs and desires and if possible by giving something personal or individual (personalization). Hotel industries have implemented these benefits by remembering the customers' names and putting guest preferences in the database so that hotel staffs can easily access this information when serving the customers.

3. Structural ties

The benefits of structural bonding (structural ties) is to build long term profitable relationships with customers by providing a structural bond that allows customers to transact with the company. These can be implemented by providing online access to the company so that customers can get any information from the company easily. They will feel appreciated and be part of the company. 
Furthermore, according to Grewal and Levy (2010), companies that practise value-based marketing use a process known as Customer Relationship Management (CRM), a business philosophy and set of strategies, programs, and systems that focus on identifying and building loyalty among the companies' most valued customers. Companies that employ CRM systematically collect information about their customers' needs and then use that information to target their best customers with the products, services, and special promotions that appear most important to those customers.

By maintaining this relationship, it is hoped that customers will be satisfied with their purchase and buy from the same company again. Loyal customers will buy only certain brands of products or services repeatedly rather than buy from multiple suppliers within the same category.

Grewal and Levy (2010) state that brand-loyal customers are an important source of value for companies. First, such customers are often less sensitive to price. In return, companies sometimes reward loyal customers with loyalty or CRM programs, such as points customers can redeem for extra discounts or free services, advance notice of sale items, and invitations to special events sponsored by the company. Second, the marketing costs of reaching loyal costumers are much lower because the company does not have to spend money on advertising and promotion campaigns to attract these customers. Loyal customers do not simply need persuasion or an extra push to buy the companies' brands. Third, loyal costomers tend to praise the virtues of their favourite products, retailers, or services to others. This positive word-of-mouth reaches potential customers and reinforces the perceived value of current customers, all at no cost to the company. Finally, a high level of brand loyalty insulates the companies from competition because loyal customers do not switch to competitors' brands, even when provided with a variety of incentives.

Companies use CRM to keep their customers in order to survive; and this can be achieved by creating customer loyalty in the long run. They are looking for customers who are committed to them. Customers who are not committed with the companies may not be loyal if other companies offer a better product or service (Zineldine, 2006).

The purpose of CRM is to make customers purchase repeatedly through different communi-

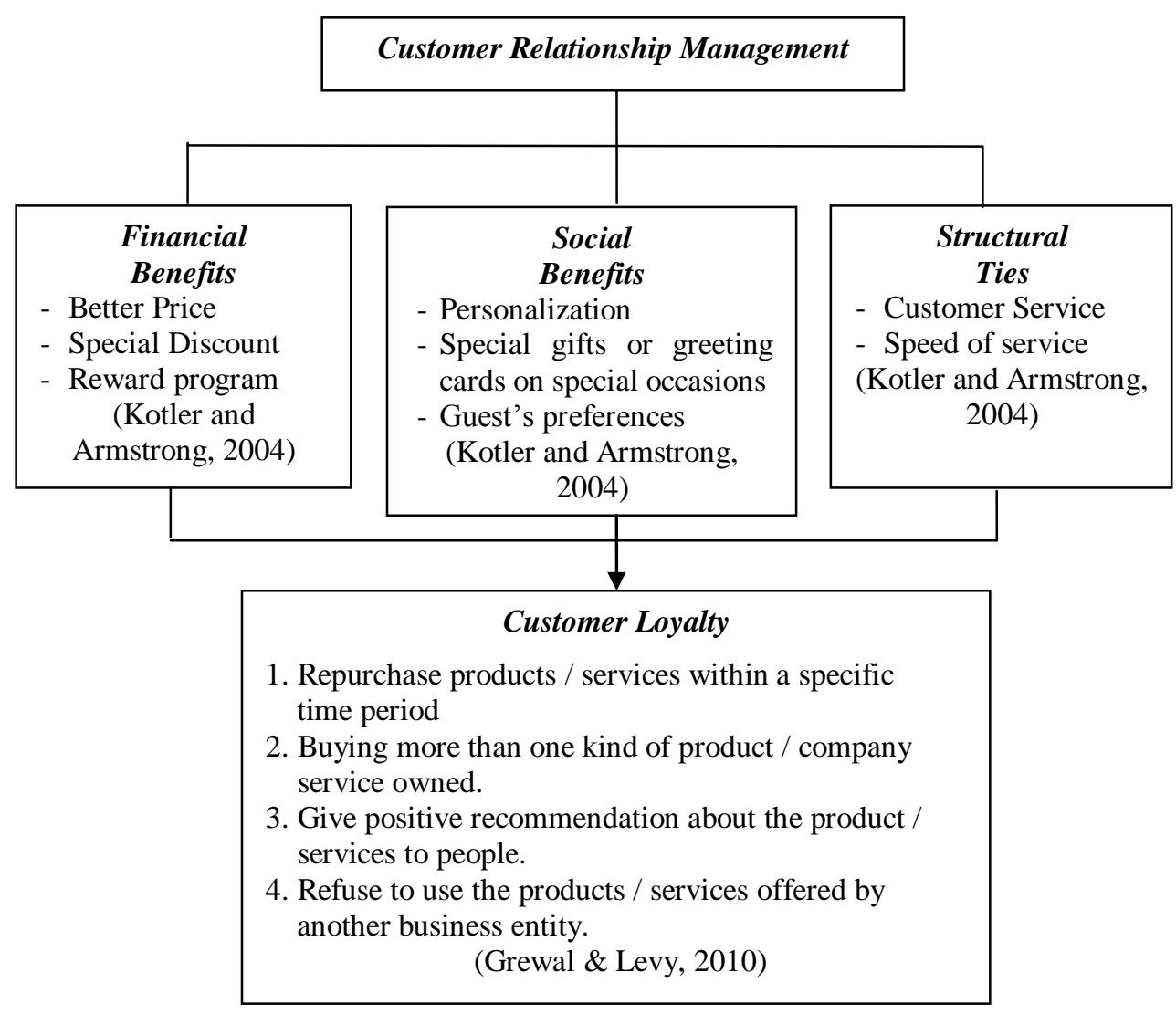

Figure 1. Research Model 
cations with them and by providing the right offer, as well as appropriate manner and time. When customers have experiences with a company that make them happy, they will be loyal to the company (Kim et al., 2008). Therefore, CRM plays an important role in the process of building and maintaining long-term profitable relationships with customers. At the same time it may also create customer loyalty.

Based on the model above, the hypothesis of the research is as follows: Financial, social benefits and structural ties have significant influences on customer loyalty in JW Marriott Hotel Surabaya.

\section{RESEARCH METHOD}

This research is descriptive explanative which is aimed to visualize numerous variables and relationships among variables (Cooper \& Schindler, 2006). A population is the total collection of elements about which the writers wish to make some inferences (Cooper \& Schindler, 2006). In this research the population is infinite.

In addition, Cooper and Schindler (2006) mention that sampling is done by selecting some of the elements in a population at which the writers may draw conclusions about the entire population. Purposive sampling is used in this research with criteria that customers are those who are members of Marriott Rewards Program, aged at least 17 years old and have already stayed in JW Marriott Hotel Surabaya minimally twice in the last year (January until December 2011). With $95 \%$ confidence for an infinite population adjustment, the sample size should be at least 81 respondents (Cooper \& Schindler, 2006). Therefore 116 samples are taken in this study.

Data are facts presented to the writers from the study's environment. Primary data are sought for their proximity to the truth and control over error. Secondary data have at least one level of interpretation inserted between the event and its recording (Cooper $\&$ Schindler, 2006).

In this research the primary data are interviews and questionnaires handed in to members of Marriott Rewards Program. Whereas, secondary data are taken from literature, journals, articles, and internet.

Operational definitions and limitations of the variables used in this research are as follows:

1. CRM (Independent Variable)

CRM is a strategy to improve the interaction between companies and customers in order to maintain a favorable relationship between the two. CRM influences customer side in some aspects, like:
- Financial Benefits $\left(X_{1}\right)$ is the economical benefits that customers get from cost saving. The indicators are:

- Marriott Rewards Program gives better price to its members

- Marriott Rewards Program gives special discounts to its members

- Marriott Rewards Program allows members to redeem their points with the desired reward they want.

- Social Benefits $\left(\mathrm{X}_{2}\right)$ are what customers get from personalized service.

The indicators of social benefits are:

- Members of Marriott Rewards Program are greeted by names.

- Members of Marriott Rewards Program get special gifts or greeting cards on their special occasions.

- Members of Marriott Rewards Program are served in accordance with their needs and desires without having to notify the hotel staff again.

- Structural Ties $\left(\mathrm{X}_{3}\right)$ refer to the easy access to services. The indicators are:

- Members of Marriott Rewards Program get greetings from Front Office Manager/ Director Of Room/ General Manager (depending on their membership type).

- Members of Marriott Rewards Program can get room reservation priority.

2. Customer loyalty (Dependent Variable)

Loyal customers are those who purchase on a regular basis or there is a condition which requires customers to buy at least twice within a certain interval. The indicators of customers loyalty are:

- Repurchase products/services within a certain period of time at JW Marriott.

- Buying more than one kind of product/ company service owned.

- Give positive recommendation about the product/services to other people.

- Refuse to use the products/services offered by other competitors.

\section{Data Analysis Technique}

1. Validity Test

Validity is the degree of accuracy in measuring the instrument or the content of the research being measured. The validity test is done to find whether each model of the questions has actually been valid using Pearson product moment correlation. If the Pearson product moment correlation in each question has a total score of significance value 
$<0.05(\alpha=5 \%)$, then the item is valid (Sugiyono, 2006).

2. Reliability Test

Reliability test is carried out in order to determine the consistency of the instrument as a measuring tool, so that the result of a measurement can be trusted. It is said to be reliable if the value of Cronbach's alpha is greater than 0.6 (Sugiyono, 2006).

3. Classic Assumption of Regression Analysis It includes normality, multicollinearity, heteroscedasticity tests, multiple linear regression, correlation analysis and multiple coefficient of determination (R2), F-test as well as t-test (Sugiyono, 2006).

\section{RESULTS AND DISCUSSIONS}

On June 10, 2002, in Washington DC, Marriott International announced that The Westin Surabaya changed its management into the JW Marriott Hotel. JW Marriott Hotel Surabaya is the Indonesia's second hotel after the first one in Jakarta. The word derives from the name of its founder JW James Wiliard. JW Marriott Hotel Surabaya is owned by PT. Surya Ramasari Persada and managed by Marriott International Inc. with the contract management system.

Based on the research, all items of the questions on financial benefits, social benefits, structural ties and customer loyalty generate significance values of Pearson product moment correlation of less than 0.05 . Thus, the items are said to be valid.

The results of reliability test show that variables of financial benefits, social benefits, structural ties and customer loyalty have Cronbach's alpha values greater than the critical value of 0.6. So the items are said to be reliable.

Table 1. Validity Test

\begin{tabular}{lcccc}
\hline Variable & Item & Correlation & Significance & Remarks \\
\hline Financial & 1 & 0.863 & 0.000 & valid \\
Benefits & 2 & 0.833 & 0.000 & valid \\
& 3 & 0.604 & 0.000 & valid \\
Social & 1 & 0.701 & 0.000 & valid \\
Benefits & 2 & 0.810 & 0.000 & valid \\
& 3 & 0.762 & 0.000 & valid \\
Structural & 1 & 0.944 & 0.000 & valid \\
Ties & 2 & 0.799 & 0.000 & valid \\
Customer & 1 & 0.858 & 0.000 & valid \\
Loyalty & 2 & 0.840 & 0.000 & valid \\
& 3 & 0.870 & 0.000 & valid \\
\hline
\end{tabular}

The result of Kolmogorov Smirnov is 0.452 which is greater than 0.05 , so it can be said that the regression model has normal distribution. It is also found that three independent variables have tolerance values greater than 0.10 and VIF values below 10 as per Table 3 below. If tolerence value $>0.10$ and VIF $<10$, the regression modesl is free from multicollinearity. So it can be concluded that there is no correlation among its independent variables.

Furthermore, the results of heteroscedasticity test show that the values of rank spearman correlation from three independent variables are greater than 0.05 as per Table 4. So it is said that the model is free from heteroscedasticity.

In addition, Table 5 shows that the value of VIF Collinearity statistics is less than 0.80 . So it can be said that the model is fit as there is no autocorrelation among its predictor variables.

Table 2. Reliability Test

\begin{tabular}{lccc}
\hline \multicolumn{1}{c}{ Variable } & $\begin{array}{c}\text { Alpha } \\
\text { Cronbach's }\end{array}$ & $\begin{array}{c}\text { Critical } \\
\text { Value }\end{array}$ & Remarks \\
\hline Financial Benefits & 0.654 & 0.6 & Reliable \\
Social Benefits & 0.622 & 0.6 & Reliable \\
Structural Ties & 0.638 & 0.6 & Reliable \\
Customer Loyalty & 0.805 & 0.6 & Reliable \\
\hline
\end{tabular}

Table 3. Multicollinearity Test

\begin{tabular}{lcc}
\hline Independent Variables & Tolerance & VIF \\
\hline Financial Benefits & 0.697 & 1.434 \\
Social Benefits & 0.485 & 2.063 \\
Structural Ties & 0.408 & 2.450 \\
\hline
\end{tabular}

Table 4. Heteroscedasticity Test

\begin{tabular}{lcc}
\hline Independent Variables & $\begin{array}{c}\text { Spearman } \\
\text { Correlation }\end{array}$ & Significance \\
\hline Financial Benefits & 0.069 & 0.463 \\
Social Benefits & 0.086 & 0.361 \\
Structural Ties & 0.013 & 0.888 \\
\hline
\end{tabular}

The relationships among financial, social benefits and structural ties towards customer loyalty in JW Marriott Hotel Surabaya can be described using the following equation:

$$
\mathrm{Y}=0.716+0.171 \mathrm{X}_{1}+0.286 \mathrm{X}_{2}+0.507 \mathrm{X}_{3}
$$

Results of R Square

It can be seen in Table 5 at which $t$ count of the three variables $>\mathrm{t}$ table $(1.981)$ and significance values of the three variables $<0.05$.

Based on the results of the research, it shows that male respondents are 79 people $(68.1 \%)$, whereas female respondents are only 37 people (31.9\%). Respondents who are housewives only 19 people (16.4\%). Respondents who work as self-employees are as many as 64 people (55.2\%), while respondents who have other professions are as 33 people (28.4\%). 
Table 5. Multiple Regression Analysis

\begin{tabular}{|c|c|c|c|c|c|c|c|}
\hline \multirow{2}{*}{\multicolumn{2}{|c|}{ Model }} & \multicolumn{2}{|c|}{$\begin{array}{c}\text { Unstandardized } \\
\text { Coefficients }\end{array}$} & \multirow{2}{*}{$\begin{array}{c}\text { Standardized } \\
\text { Coefficients } \\
\text { Beta }\end{array}$} & \multirow[t]{2}{*}{$\mathbf{t}$} & \multirow[t]{2}{*}{ Sig. } & \multirow{2}{*}{$\begin{array}{c}\text { Collinearity } \\
\text { Statistics } \\
\text { VIF }\end{array}$} \\
\hline & & B & Std. Errror & & & & \\
\hline \multirow[t]{4}{*}{1} & (Constant) & 0.716 & 0.245 & & 2.918 & 0.004 & \\
\hline & Financial Benefits & 0.171 & 0.082 & 0.144 & 2.079 & 0.040 & 0.193 \\
\hline & Social Benefits & 0.286 & 0.093 & 0.257 & 3.094 & 0.002 & 0.281 \\
\hline & Structural Ties & 0.507 & 0.092 & 0.497 & 5.489 & 0.000 & 0.460 \\
\hline
\end{tabular}

Results of R Square

Table 6. Value of $\mathbf{R}$ and $\mathbf{R}$ Square

\begin{tabular}{ccccc}
\hline Model & R & R Square & Adjusted R Square & Std. Error of the Estimate \\
\hline 1 & 0.791 & 0.626 & 0.616 & 0.45081 \\
\hline
\end{tabular}

Results of F Test

Table 7. F Test Analysis

\begin{tabular}{llccccc}
\hline & Model & Sum of Squares & df & Mean Square & F & Sig. \\
\hline 1 & Regression & 38.045 & 3 & 12.682 & 62.400 & 0.000 \\
& Residual & 22.762 & 112 & 0.203 & & \\
Total & 60.807 & 115 & & & \\
\hline
\end{tabular}

Results of t-test

Respondents aged 17 to 30 years are only 10 people $(8.6 \%)$, respondents aged 31 to 45 years are 43 people $(37.1 \%)$. Respondents aged 46 to 55 years are as many as 47 people $(40.5 \%)$, while respondents aged over 55 years are 16 people $(13.8 \%)$. Within 1 year, respondents who last visited JW Marriott Hotel Surabaya twice are 61 people $(52.6 \%)$; while respondents in the last year to visit JW Marriott Hotel Surabaya more than twice are 55 people $(47.4 \%)$.

These results indicate that the majority of customers who are members of Marriott Rewards Program in JW Marriott Hotel Surabaya are males, working as entrepreneurs, aged 31 to 55 years. The majority of them are those who visited twice in the previous year.

\section{Discussions}

The value of 0.716 in regression equation shows that customers have already been loyal if supposed financial benefits, social benefits and structural ties are 0 (zero). Even though there are no financial, social benefits and structural ties offered by the hotel, the value of customer loyalty is high enough.

Furthermore, Table 7 shows that $\mathrm{F}$ count value is $62.40>$ F table 2.686 with significance of $0.000<$ 0.05 so the model is fit. Based on Table 6, it is known that $\mathrm{R}$ value is 0.791 which shows that the relationships among financial benefits, social benefits and structural ties with customer loyalty in JW Marriott Hotel Surabaya is very strong. The value of $\mathrm{R}$ square is 0.626 which shows the influence of independent variables (financial, social benefits and structural ties) altogether to dependent variable (customer loyalty) is $62.6 \%$, whereas the rest of $37.4 \%$ is influenced by other factors. So it can be concluded that the hypothesis stating financial, social benefits and structural ties have significant influences on customer loyalty in JW Marriott Hotel Surabaya is proven. It is in line with Grewal and Levy (2010) who state that CRM can be used as a strategy to build and maintain loyalty among the companies' most valued customers.

Table 5 shows that these three variables also have $t$ count $>t$ table (1.981) and significance values $<0.05$. So it can be said that financial, social benefits and structural ties have positive and significant influences on customer loyalty in JW Marriott Hotel Surabaya. First, members of Marriott Rewards Program can redeem their reward points as desired. For them having special discounts is not that important as most of them are from middle and upper class society who are not price conscious. It is in line with Grewal and Levy (2010) who state that such customers are often less sensitive to price. Second, they can get the services in accordance with their needs and desires without having to notify the hotel again. At the time of the members doing the check-in 
at the hotel, the computer system will automatically provides specific information about their preferences, for example: they are greeted personally by Front Office Manager/ Director of Room or General Manager depending on their membership types (silver, gold or platinum) and served with welcome drink; they may also be allocated into their preferred room as the hotel has every single detail about customers' preferences in the database. Kim et al. (2008) support this because by providing the right offer, as well as appropriate manner and time, it will make customers happy and loyal to the company. Finally, they can also have easy access to get any information from the hotel, especially in reservation process. They may also get some priority, special offers and guarantee to get the desired room they want.

Among the three variables, structural ties is the most dominant influence variable on customer loyalty in JW Marriott Hotel Surabaya as its beta coefficient is 0.507 which is higher than the other two variables and its significance is 0.000 . For members of Marriott Rewards Program, it is much more important to get easy access on line to the hotel as they feel appreciated to be part of the hotel. This bond of relationship is shown by an easy room reservation process when staying, which is a priority and guarantee for them to get a room. They also feel the friendliness of the hotel staff because the hotel has made them as a structural part of the hotel. The General Manager (GM) and other managers on duty will great them personally depending on the membership types. Whenever the GM is not on duty, they will get greeting cards handwritten by the GM or even special room set-up. This special care can make them loyal to the hotel. As stated by Kim et al. (2008) when customers have experiences with a company that make them happy, they will be loyal to the company.

\section{CONCLUSIONS AND RECOMMENDATIONS}

CRM that includes financial benefits, social benefits and structural ties has significant influences on customer loyalty in JW Marriott Hotel Surabaya. It is indicated by F count value (62.40) which is greater than $\mathrm{F}$ table (2.686) with significance of $0.000<0.05$; and $t$ count of three variables $(2.079 ; 3.094$, and 3.094) which are greater than $t$ table (1.981) and significance values $<0.05$. So the increased financial benefits, social benefits and structural ties will increase customer loyalty in JW Marriott Hotel Surabaya.

Among the three independent variables, the most dominant influence is structural ties. It is indicated by the largest partial beta coefficient of 0.507 which is greater than the other two variables. Thus, the increase of structural ties will increase customer loyalty in JW Marriott Hotel Surabaya.

From the analysis and conclusions obtained, the writers suggest the followings: The financial benefits of CRM run by JW Marriott Hotel Surabaya need to be maintained and improved because these factors are proven to increase customer loyalty. So far, JW Marriott has a partnership with Mitra Adi Perkasa Inc. (MAP) through coupon purchases at the outlets of MAP. Some brands under MAP are Sogo Department Store, Sport Warehouse, Marks \& Spencer, Zara, Stacatto, NEXT, Rockport, Starbucks, DKNY, Converse, Sport Station, Kipling, Nautica, Nine West. This collaboration is expected to be an additional advantage for members of Marriott Rewards Program, in addition to redeem points for free with a coupon to stay at JW Marriott Hotel Surabaya or other Marriott International hotels. Moreover, JW Marriott Hotel Surabaya can cooperate with more merchants that attract members' interests. So they can exchange or redeem the points they get with shopping vouchers and the like. Hopefully this will increase their loyalty because the results show that members of Marriott Rewards Program agree with financial benefits allowing them to redeem the points with desired rewards.

To improve social benefits of its Marriott Reward members, JW Marriott Hotel Surabaya can try to understand the history of its members and provide an online greeting cards sent to each member on their birthdays or any other special occasions, like anniversary. Provision of speech should be done not only to members who are staying in the hotel while having their birthdays but also to members who are not staying in the hotel on their birthdays. This can be done by phone or email. Apart from this, inclusionpromo and greeting cards can be sent to attract members to celebrate their special moments in the hotel and to show hotel's concern to its customer special moments. In this way the customers are expected to be more loyal to the hotel.

The structural ties need to be maintained and improved because they prove to be the most dominant factor influencing customer loyalty. Apart from giving special priority and room guarantee or availability, JW Marriott Hotel can also send special offers or promotions by email or using other means of communication to members of Marriott Rewards Program.

For further research, the researcher can study other factors than financial, social benefits and structural ties that influence customer loyalty in JW Marriott Hotel Surabaya. 


\section{REFERENCES}

Cooper, D.R. \& Schindler, P.S. 2006. Business Research Methods. $9^{\text {th }}$ Edition. New York: McGraw-Hill.

Grewal, D. \& Levy, M. 2010. Marketing. $2^{\text {nd }}$ Edition. New York: McGraw-Hill Irwin.

Kim, K.H., Kim, K.S., Kim, D.Y., Kim, J.H. \& Kang, S.H. 2008. Brand Equity in Hospital Marketing. Journal of Organization Research, 61:75-82.

Kotler, P. \& Armstrong, G. 2004. Principles of Marketing. $10^{\text {th }}$ Edition. New Jersey: Prentice Hall.

Mcllroy, A. \& Barnet S. 2000. Building Customer Relationships: Do discount cards work? Managing Service Quality, 10(6): 347-55.
Persson, P. 2004. Customer Relationship Management and How CRM System Can be Used in the Sales Process. Unpublished Thesis. Stockholm: Lulea University of Technology. (http://epubl. ltu.se/1402-1617/2004/124/LTU-EX-04124-SE. pdf, retrieved)

Shoemaker, S., \& Lewis, R.C. 1999, Customer Loyalty: The Future of Hospitality Marketing. Hospitality Management, 18(4): 345 - 370.

Sugiyono. 2006. Metode Penelitian Pendidikan; Pendekatan Kuantitatif, Kualitatif dan $R \& D$. Bandung: Alfabeta.

Zineldine, M. 2006. The Royalty of Loyalty: CRM, Quality and Retention. Journal of Consumer Marketing, 23(7): 430-437. 